\title{
Long-Term Trends in Small Mammals on a Right-of-Way in Pennsylvania, U.S.
}

\author{
Richard H. Yahner, Richard T. Yahner, and Russell J. Hutnik
}

\begin{abstract}
The State Game Lands 33 Research and Demonstration Area, Centre County, Pennsylvania, U.S., has been studied since 1953 with the objective of comparing the effectiveness of commonly used mechanical and herbicidal maintenance treatments on vegetation and wildlife on a right-of-way (ROW). Small mammals are important wildlife species on a ROW by consuming tree seeds, thereby reducing invasion of undesirable tree species, and these mammals are important components of a healthy ecosystem. As a follow up to a 2-year study of small mammals conducted 15 years earlier (1989 to 1990) on the State Game Lands 33 ROW, we initiated a 2-year live-trapping study in 2004 on small mammal populations on this ROW. The objectives of our study were to determine relative abundance and species richness (number of species) in six major cover types and in the adjacent forest. One hundred twenty-one individuals of eight species were observed in 2004 and 2005 combined; the most common species was the white-footed mouse (Peromyscus leucopus). One of the most important cover types to small mammals on the ROW was forb-grass, whereas the forest cover type tended to be less diverse in terms of number of mammal species than in cover types on the ROW.
\end{abstract}

Key Words. Herbicides; Pennsylvania; populations; right-of-way; small mammals; vegetation.

The State Game Lands (SGL) 33 Research and Demonstration Project has two objectives since 1953: (1) to compare the effectiveness of commonly used mechanical and herbicidal maintenance treatments on control of target (undesirable) trees and development of tree-resistant plant cover types, and (2) to determine the effect of mechanical and herbicidal maintenance on vegetation (wildlife habitat) and wildlife species of high public interest (Bramble and Byrnes 1996; Yahner and Hutnik 2004). The wire-border zone method of vegetation management was implemented on the right-of-way (ROW) of the SGL 33 Research and Demonstration Project in 1982 (Bramble et al. 1985) (Figure 1). This method of vegetation management typically produces a tree-resistant forbshrub-grass cover type in wire zones and a tall shrub cover type in border zones. The wire-border zone method provides a diverse wildlife habitat on the ROW with low-lying vegetation in the wire zone and taller vegetation in the border zone to create habitat diversity.

Small mammals such as mice and shrews are important wildlife species on an electric transmission ROW (Bramble et al. 1992). Small mammals consume tree seeds (Merritt 1987), thereby reducing invasion of undesirable tree species in wire and border zones of a ROW. Small mammals also are important components of a healthy ecosystem by serving as prey for a variety of carnivores, e.g., hawks, owls, and foxes (Merritt 1987). In a previous study conducted in 1989 to 1990
(Bramble et al. 1992), seven species of small mammals were noted on the SGL 33 ROW, and mammals used a diversity of cover types.

Long-term studies of small mammals on a ROW are nonexistent. Thus, as a follow up to the mammal study conducted 15 years earlier (Bramble et al. 1992), we initiated a 2-year study in 2004 on small mammal populations on the SGL 33 Research and Demonstration Area. The objectives of the current study were to determine relative abundance and species richness (number of species) in six major cover types along the ROW resulting from herbicidal and mechanical maintenance of the vegetation. In addition, small mammal populations on the ROW were compared with those in the adjacent forest.

\section{STUDY AREA AND METHODS}

Treatments used on the SGL 33 Research and Demonstration Area in 2000 consisted of two units each of handcut, mowing, mowing plus herbicide, stem-foliage spray, foliage spray, and low-volume basal spray (details of the treatments are given in Yahner and Hutnik 2004, 2005) (Figure 2). Seven cover types selected for study were based on dominant life forms (tree, shrub, forb, and grass), which followed the approximate methodology of Bramble et al. (1992): (1) adjacent forest, (2) tree sprout, (3) tall shrub, (4) short shrub, (5) cane thicket, (6) forb-grass, and (7) grass. 


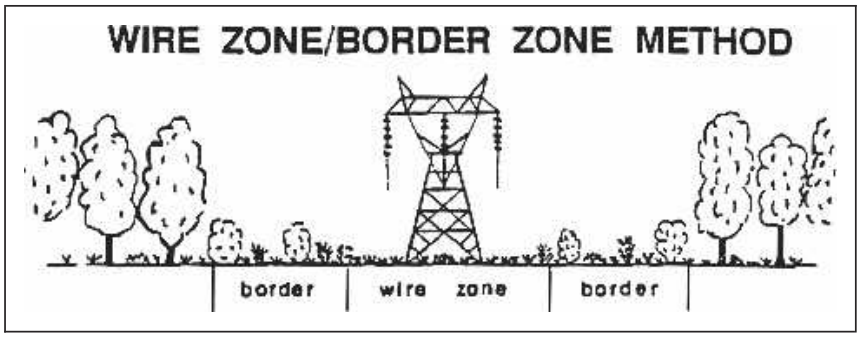

Figure 1. Diagram of a $230 \mathrm{kV}$ electric transmission line showing wire and border zone. A combination of a lowgrowing forb-shrub-grass cover type usually develops in the wire zone, and a tall shrub cover type occurs in the border zone. Adjacent to the border zone is mature forest.

Forest cover type was located $50 \mathrm{~m}$ (165 ft) adjacent to the ROW (near a handcut and a basal low-volume spray unit); dominant trees were chestnut oak (Quercus montanus), northern red oak (Quercus rubra), white oak (Quercus alba), and black oak (Quercus velutina). Tree sprout cover type was produced by a handcut unit with common tree species being chestnut, northern red, white, black, and scrub (Quercus ilicifolia) oaks and black cherry (Prunus serotina). Tall shrub cover type predominated in border zones of several treatment units, e.g., mowing plus herbicide, with a dominant tall shrub of witchhazel (Hamamelis virginiana). Short shrub cover type commonly occurred in wire zones of some units, e.g., basal low-volume spray, and the principal plant species were blueberry (Vaccinium vacillans and Vaccinium angustifo-

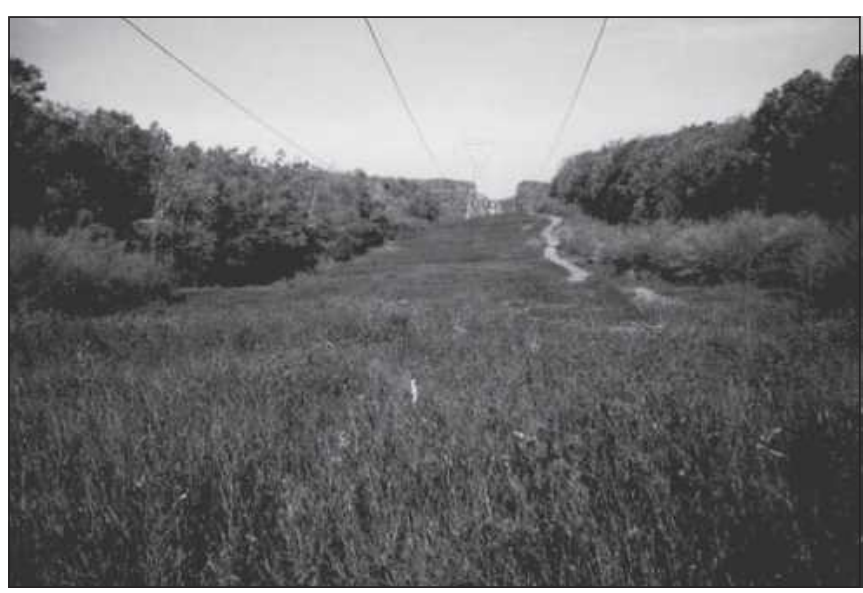

Figure 2. A northerly view of the right-of-way on the State Game Lands 33 Research and Demonstration Area, Centre County, Pennsylvania. In the foreground is a basal low-volume spray unit showing the foliage of black chokeberry (Aronia melanocarpa). The flagging is the location of a permanent plot used for vegetation transect establishment (photo by R. Yahner, early November 2005). lium), huckleberry (Gaylussacia baccata), and sweet-fern (Comptonia peregrina). Cane thicket cover type was present in pure stands of some wire zones, e.g., basal low-volume spray, and the major species was common blackberry (Rubus allegheniensis). Forb-grass cover type was common in wire zones of mowed plus herbicide units; major species included goldenrod (Solidago rugosa and Euthamia graminifolia), hayscented fern (Dennstaedtia punctilobula), and poverty grass (Danthonia spicata). Grass cover type was present in wire zones of some units treated with mowing, which often contained dense stands of tall meadow fescue (Festuca elatior).

Mammals were surveyed monthly from May through November in 2004 and 2005 in each of the seven cover types. Six metal live traps were spaced in a $2 \times 3$ grid in a $10 \times 15$ $\mathrm{m}(33 \times 50 \mathrm{ft})$ area in each cover type (after Yahner 1988). Traps were baited with a small amount of peanut butter, and a ball of fiber was placed in each trap for bedding just before dusk. Each trap was checked for captured small mammals on two consecutive mornings. Species, number of individuals trapped, date of capture, and location of capture relative to cover types were noted for each monthly survey (Smith and Vrieze 1979; Yahner 1983). Sex (if known), age (if known), reproductive condition (e.g., pregnant, lactating, scrotal), and individual identification (e.g., ear tag or toe clip) were recorded for each captured mammal (Rose and Dueser 1980). A total of 588 trap-nights (TN) was sampled per year based on seven monthly surveys per year.

\section{RESULTS AND DISCUSSION}

One hundred twenty-one individuals of eight small mammal species were found on the ROW and adjacent forest in 2004 and 2005 combined (Table 1). In contrast, seven species were noted on the ROW in 1989 and 1990 (Bramble et al. 1992). Based on 1176 total TN in the current study, capture frequency in all cover types and both years combined represented 10.3 animals captured/100 TN; in 1989 and 1990, number of individuals captured/100 TN in all cover types combined on the ROW averaged 27.0 (Bramble et al. 1992). We have no biologic explanation for this reduction in small mammals from 1989 and 1990 to the current study that could be attributed to population cycles, differential predation rates, or herbicidal use. Significant differences in mammal populations have been noted elsewhere in central Pennsylvania for no apparent reason (Yahner 1988). One factor may be in the impact of herbicidal use on small mammals, but no long-term impact has been noted on bird populations (or their food resources, e.g., insect larvae) on the same ROW (Bramble et al. 1999; Yahner et al. 2002).

Six and eight species were noted on the ROW in 2004 and 2005, respectively (Table 1). Similarly, number of individual animals captures/100 TN was lower in 2004 (6.3) than in 2005 (14.3). In contrast, the small mammal community on 
Table 1. Number of individual small mammals (number of animals recaptured in parentheses) captured by cover type on the SGL 33 Research and Demonstration Area, May through November 2004 and 2005.*

\begin{tabular}{|c|c|c|c|c|c|}
\hline Month & Cover type & Species & 2004 & 2005 & Total \\
\hline \multirow[t]{3}{*}{ May } & Tree sprout & White-footed mouse & 0 & 2 & 2 \\
\hline & Forb-grass & Meadow vole & 0 & 2 & 2 \\
\hline & Grass & Meadow Vole & 0 & 1 & 1 \\
\hline \multirow[t]{8}{*}{ June } & Tree sprout & Eastern chipmunk & 0 & 1 & 1 \\
\hline & Tree sprout & White-footed mouse & 0 & 1 & 1 \\
\hline & Cane thicket & Eastern chipmunk & 0 & 1 & 1 \\
\hline & Cane thicket & White-footed mouse & 0 & 2 & 2 \\
\hline & Cane thicket & Deer mouse & 0 & 1 & 1 \\
\hline & Forb-grass & Deer mouse & 0 & 2 & 2 \\
\hline & Forb-grass & Meadow vole & 0 & 5 & 5 \\
\hline & Grass & Meadow vole & 0 & 2 & 2 \\
\hline \multirow[t]{10}{*}{ July } & Forest & White-footed mouse & 1 & $4(1)$ & 5 \\
\hline & Tree sprout & Deer mouse & 1 & 0 & 1 \\
\hline & Short shrub & Masked shrew & 0 & 1 & 1 \\
\hline & Short shrub & Southern red-backed vole & 0 & 2 & 2 \\
\hline & Cane thicket & Eastern chipmunk & 0 & 1 & 1 \\
\hline & Cane thicket & Deer mouse & 0 & 1 & 1 \\
\hline & Cane thicket & White-footed mouse & 0 & 4 & 4 \\
\hline & Forb-grass & White-footed mouse & 0 & $2(4)$ & 2 \\
\hline & Forb-grass & Meadow vole & 0 & $2(3)$ & 2 \\
\hline & Grass & Meadow vole & 0 & 4 & 4 \\
\hline \multirow[t]{9}{*}{ August } & Forest & White-footed mouse & $5(1)$ & $3(3)$ & $8(4)$ \\
\hline & Tall shrub & Deer mouse & 1 & 0 & 1 \\
\hline & Tall shrub & White-footed mouse & 0 & $4(3)$ & $5(3)$ \\
\hline & Short shrub & White-footed mouse & 0 & 1 & 1 \\
\hline & Cane thicket & Short-tailed shrew & 2 & 0 & 2 \\
\hline & Cane thicket & Eastern chipmunk & 0 & 1 & 1 \\
\hline & Cane thicket & White-footed mouse & 0 & $2(2)$ & 2 \\
\hline & Grass & White-footed mouse & 0 & $1(1)$ & $1(1)$ \\
\hline & Grass & Meadow vole & 0 & 1 & 1 \\
\hline \multirow[t]{8}{*}{ September } & Forest & White-footed mouse & 2 & 1 & 3 \\
\hline & Tall shrub & Deer mouse & $2(2)$ & 0 & $2(2)$ \\
\hline & Tall shrub & White-footed mouse & 0 & $2(2)$ & $2(2)$ \\
\hline & Short shrub & Meadow vole & 0 & 1 & 1 \\
\hline & Cane thicket & Eastern chipmunk & 0 & 1 & 1 \\
\hline & Cane thicket & White-footed mouse & 0 & $2(2)$ & $2(2)$ \\
\hline & Cane thicket & Ermine (short-tailed weasel) & 1 & 0 & 1 \\
\hline & Forb-grass & Meadow vole & 0 & 2 & 2 \\
\hline \multirow[t]{12}{*}{ October } & Forest & White-footed mouse & $2(1)$ & 0 & $2(1)$ \\
\hline & Forest & Eastern chipmunk & 1 & 0 & 1 \\
\hline & Tall shrub & Short-tailed shrew & 0 & 1 & 1 \\
\hline & Tall shrub & White-footed mouse & 0 & $2(2)$ & $2(2)$ \\
\hline & Short shrub & Eastern chipmunk & 0 & $1(1)$ & $1(1)$ \\
\hline & Short shrub & Deer mouse & 1 & 0 & 1 \\
\hline & Short shrub & Meadow vole & 1 & 0 & 1 \\
\hline & Cane thicket & Deer mouse & 1 & 0 & 1 \\
\hline & Forb-grass & Short-tailed shrew & 3 & 0 & 3 \\
\hline & Forb-grass & Meadow vole & 3 & 0 & 3 \\
\hline & Forb-grass & Ermine & 0 & 1 & 1 \\
\hline & Grass & Meadow vole & 1 & 0 & 1 \\
\hline \multirow[t]{3}{*}{ November } & Forest & White-footed mouse & 0 & 1 & 1 \\
\hline & Tall shrub & Deer mouse & 0 & 1 & 1 \\
\hline & Tall shrub & White-footed mouse & 0 & 1 & 1 \\
\hline
\end{tabular}


Table 1. Number of individual small mammals (number of animals recaptured in parentheses) captured by cover type on the SGL 33 Research and Demonstration Area, May through November 2004 and 2005.* (continued)

\begin{tabular}{llllll}
\hline Month & Cover type & Species & 2004 & 2005 & Total \\
\hline November & Short shrub & White-footed mouse & 3 & $1(1)$ & 4 \\
& Short shrub & Meadow vole & 0 & 1 & 1 \\
& Cane thicket & White-footed mouse & 4 & 4 & 8 \\
& Forb-grass & Deer mouse & 1 & 2 & 3 \\
& Forb-grass & White-footed mouse & 0 & 1 & 1 \\
& Forb-grass & Meadow vole & 1 & 1 & 2 \\
Total number of species & Grass & White-footed mouse & 0 & 1 & 1 \\
Total number of individuals & & 6 & 8 & 8 \\
\hline
\end{tabular}

*Scientific names of small mammals are given in the text.

SGL 33 was much more diverse than that found on the ROW at the Green Lane Research and Demonstration Area in southeastern Pennsylvania (Montgomery County) in 2005, where only three species were noted; also, only 5.4 individuals/100 TN in all cover types combined were recorded on the Green Lane ROW in 2005 (Yahner et al. 2005).

Of the eight species recorded on the ROW in 2004 and 2005 combined, the most common was the white-footed mouse (Peromyscus leucopus; $n=60$ individuals [49.6\% of total individuals]), meadow vole (Microtus pennsylvanicus; $n=29[24.0 \%]$ ), deer mouse ( $P$. maniculatus; $n=14$ [11.6\%]), eastern chipmunk (Tamias striatus; $n=7$ [5.8\%]), northern short-tailed shrew (Blarina brevicauda; $n=6$ [5.0\%]), southern red-backed vole (Clethrionomys gapperi; $n=2[1.7 \%]$ ), ermine (Mustela erminea; $n=2[1.7 \%]$ ), and masked shrew (Sorex cinereus; $n=1[0.8 \%]$ ) (Table 1). White-footed mice were ubiquitous on the ROW with captures occurring in each of the cover types in 2004 to 2005; this species is probably the most common small mammal in wooded habitats throughout Pennsylvania (Merritt 1987). Eastern chipmunks, deer mice, and meadow voles were noted in at least three different cover types in the 2 years. Species found on the ROW in 2004 and 2005 but not in 1989 and 1990 were deer mouse and ermine; conversely, species found in 1989 and 1990 on the ROW but not in 2004 and 2005 were one each of woodland (Napaeozapus insignis) and meadow jumping mice (Zapus hudsonicus) (Bramble et al. 1992).

Number of species and total individuals of all species combined (percentage of total individuals and number of individuals of all species combined/100 TN given in parentheses) varied among cover types on SGL 33 in 2004 and 2005 combined: grass $=2$ species, 11 individuals $(9.1 \%$ of total individuals, $0.9100 / \mathrm{TN}$ ); forest $=2$ species, 20 individuals $(16.5 \%, 1.7)$; tall shrub $=3$ species, 15 individuals $(12.4 \%$, 1.3); both cane thicket and forb-grass each $=5$ species, 28 individuals $(23.1 \%, 2.4)$; and short shrub $=6$ species, 6 individuals $(5.0 \%, 0.5)$ (Table 1). Hence, like in a previous study (Bramble et al. 1992), the forest cover type tended to be less diverse in terms of number of mammal species than cover types on the ROW but populations were lowest in grass cover type. Small mammal diversity would be expected to be greater on the ROW with heterogeneous vegetative structure compared with the more homogeneous forest (after Anthony et al. 1981).

One of the most important cover types to small mammals, e.g., forb-grass, on the ROW was the result of integrated vegetation management in the wire zone of a mowing plus herbicide unit, whereas the cane thicket cover type and the short shrub cover type were created by integrated vegetation management in wire zones of basal low-volume spray units (Yahner and Hutnik 2004). In particular, forb-grass was an important cover type for the meadow vole, which is a grassland specialist (Grant 1971).

Number of mammals captured varied between years with none found earlier in the year (May to June) in 2004, but 23 individuals were captured in these 2 months in 2005 (Table 1). These data attest to the value of conducting a study on flora and fauna for more than 1 year. Small mammals on the ROW increased in numbers subsequent to May (June through early November) in both years combined; small mammal abundances tend to increase from spring through autumn (Yahner 1983; Merritt 1987).

The relative lack of mammals on the ROW and in the forest in May of both years is not surprising based on other studies (e.g., Beer 1961; Yahner 1983); in spring, for instance, abundance of small mammals is low, and movements by individuals probably are reduced. As the year progressed, reproduction and food resources increased, thereby resulting in more mammals found on the ROW. In August, in particular, black chokeberry (Aronia melanocarpa), low-sweet blueberry (Vaccinium angustifolium), and common blackberry were fruiting, which likely accounted for relatively large numbers of captures in this month on the ROW.

Acknowledgments. Cooperators were Asplundh Tree Expert Co., Dow AgroSciences, FirstEnergy, and the Pennsylvania Game Com- 
mission. We thank E. Hill for assistance with manuscript preparation.

\section{LITERATURE CITED}

Anthony, R.G., L.J. Niles, and J.D. Spring. 1981. Small mammal associations in forested and old-field habitats-a quantitative comparison. Ecology 62:955-963.

Beer, J.R. 1961. Winter home ranges of the red-backed mouse and the deer mouse. Journal of Mammalogy 42: 174-180.

Bramble, W.C., and W.R. Byrnes. 1996. Integrated vegetation management of an electric utility right-of-way ecosystem. Down to Earth 51:29-34.

Bramble, W.C., W.R. Byrnes, and R.J. Hutnik. 1985. Effects of a special technique for right-of-way maintenance on deer habitat. Journal of Arboriculture 11:278-284.

Bramble, W.C., R.H. Yahner, and W.R. Byrnes. 1999. Effect of herbicide maintenance of an electric transmission line right-of-way on butterfly populations. Journal of Arboriculture 25:302-310.

Bramble, W.C., R.H. Yahner, W.R. Byrnes, and S.A. Liscinsky. 1992. Small mammals in plant cover types on an electric transmission right-of-way. Journal of Arboriculture 18:316-321.

Grant, P.R. 1971. The habitat preference of Microtus pennsylvanicus and its relevance to the distribution of this species on an island. Journal of Mammalogy 52:351-356.

Merritt, J.D. 1987. Guide to the Mammals of Pennsylvania. Univ. Pittsburgh Press, PA. 408 pp.

Rose, R.K., and R.D. Dueser. 1980. Lifespan of Virginia meadow voles. Journal of Mammalogy 61:760-763.

Smith, A.T., and J.M. Vrieze. 1979. Population structure of Everglades rodents: Responses to a patchy environment. Journal of Mammalogy 60:778-794.

Yahner, R.H. 1983. Small mammals in farmstead shelterbelts: Habitat correlates of seasonal abundance and community structure. Journal of Wildlife Management 47: 74-84.

1988. Small mammals associated with even-aged aspen and mixed-oak forest stands in central Pennsylvania. Journal of the Pennsylvania Academy of Science 62: 122-126.

Yahner, R.H., and R.J. Hutnik. 2004. Integrated vegetation management on an electric transmission right-of-way in Pennsylvania, U.S. Journal of Arboriculture 30:295-300.

. 2005. Plant species richness on an electric transmission right-of-way using integrated vegetation management. Journal of Arboriculture 31:124-130.

Yahner, R.H., R.J. Hutnik, and S.A. Liscinsky. 2002. Bird populations associated with an electric transmission rightof-way. Journal of Arboriculture 28:123-130.
Yahner, R.H., R.J. Hutnik, and R.T. Yahner. 2005. Green Lane Research and Demonstration Project: 19 Years of Continuous Study. Annual Report to Cooperators. 26 pp.

Richard H. Yahner (corresponding author)

School of Forest Resources

College of Agricultural Sciences

The Pennsylvania State University

University Park, PA 16802, U.S.

rhy@psu.edu

Richard T. Yahner

School of Forest Resources

College of Agricultural Sciences

The Pennsylvania State University

University Park, PA 16802, U.S.

Russell J. Hutnik

School of Forest Resources

College of Agricultural Sciences

The Pennsylvania State University

University Park, PA 16802, U.S.

Résumé. La zone de recherche et de démonstration de State Game Lands (SGL) 33 dans le comté de Centre en Pennsylvanie (ÉtatsUnis) a été étudiée depuis 1953 avec l'objectif de comparer l'efficacité de différents types communs d'interventions d'entretien mécaniques et avec herbicides en regard du contrôle de la végétation et de la diversité faunique au sein d'une emprise de ligne électrique de transport. Les petits mammifères sont un élément important de la faune présente dans l'emprise en raison de leur consommation de semences, ce qui permet de réduire l'invasion par des espèces indésirables d'arbres, et aussi du faits qu'ils constituent une composante importante d'un écosystème sain. Pour les fins d'un suivi effectué deux ans après une étude sur les petits mammifères ayant débuté 15 ans auparavant (1989-1990) de la zone SGL 33, nous avons initié en 2004 une étude de 2 ans par une capture des populations de petits mammifères de cette emprise. Les objectifs de notre étude étaient de déterminer l'abondance relative et la richesse en espèces (nombre d'espèces) au sein de six types majeurs de couvert végétal et au sein de la forêt adjacente. Cent vingt et un individus de huit espèces ont été observés dans les années 2004 et 2005 combinées ensembles; l'espèce la plus commune était la souris à pattes blanches (Peromyscus leucopus). L'un des couverts les plus importants pour les petits mammifères au sein de l'emprise était celui de graminées, là où le couvert forestier tendait à être moins diversifié en terme de nombre d'espèces de mammifères, et ce par rapport aux autres types de couvert végétal dans l'emprise.

Zusammenfassung. Die SGL 33 Forschungs- und Demonstrationsregion in Pennsylvanien studiert seit 1953 mit der Absicht, die Effektivität von gewöhnlich angewendeten mechanischen und chemischen Behandlungsmethoden bei der Kontrolle von Vegetation und Fauna unter Elektrischen Überlandleitungen (ROW) zu vergleichen. Kleine Säugetiere sind wichtige Tierarten in diesem Bereich, 
indem sie Baumfrüchte und Samen vertilgen und dabei eine Invasion unerwünschter Baumarten verhindern. Und diese Säugetiere sind wichtige Komponenten eines gesunden Ökosystems. In einer bis zu zweijährigen Studie an kleinen Säugetieren, die vor 15 Jahren (1989 - 1990) in dem gleichen Bereich der ROW durchgeführt wurde, initiierten wir eine zweijährige Studie mit Fallen für diese Kleinsäuger. Die Ziele unserer Studie lagen darin, die relative Bevölkerungsdichte und Artenvielfalt in sechs Hauptbedeckungstypen und dem benachbarten Forst zu bestimmen. 121 Individuen von acht Arten wurden in 2004 und 2005 zusammengenommen beobachtet. Das gewöhnlichste Tier war die weißfüßige Maus (Peromyscus leucopus). Eine der wichtigsten Bedeckungstypen für Kleinsäuger ist Hochgras, während der Forsttyp weniger diversifiziert war als die Bedeckungstypen unter der ROW in Bezug auf Anzahl der Tierarten.

Resumen. El Área de Investigación Demostrativa del Condado Central, State Game Lands (SGL) 33, Pennsylvania, U.S., ha sido estudiada desde 1953 con el objetivo de comparar la efectividad de los tratamientos de mantenimiento mecánicos y herbicidas comúnmente usados en la vegetación y vida silvestre en los derechos de vía (ROW, por sus siglas en inglés). Los pequeños mamíferos son especies importantes de vida silvestre, y estos mamíferos son componentes valiosos de un ecosistema saludable. Como continuación del estudio de pequeños mamíferos llevado a cabo 15 años antes (19891990) en el SGL 33 ROW, se inició un estudio de trampeo en 2004 en poblaciones pequeñas en este ROW. Los objetivos del estudio fueron determinar la abundancia relativa y la riqueza de especies (número de especies) en los seis principales tipos de cobertura y en el bosque adyacente. Se observaron 121 individuos de ocho especies en 2004 y 2005; la especie más común fue el ratón de patas blancas (Peromyscus leucopus). Uno de los más importantes tipos de cobertura en el ROW fueron los pastos, mientras que el tipo de cobertura forestal tendió a ser menos diverso en términos del número de especies de mamíferos que los tipos de cobertura en el ROW. 